\title{
Reviewing Government Policy on Rice Price: Study Through Rice Price In East Java Market
}

\author{
Zainal Abidin, Resti Prastika Destiarni ${ }^{1}$, Fanny Septya \\ Agribusiness Department \\ Universitas Pembangunan Nasional "Veteran" Jawa Timur \\ Surabaya, Indonesia \\ ${ }^{1}$ restidestiarni.agrisbis@upnjatim.ac.id
}

\begin{abstract}
That HET is considered too low to absorp farmer's rice so that rice processing industry becomes farmer's choice to sell rice and their product become choice on middle and upper class consumer, especially urban society. This research was conducted to analyze the HET policy by forecasting on rice price through study in East Java market during 12 months later (June 2019). This research got a monthly rice price in East Java during January 2014 - June 2018 which was obtained from SIKAPERBAPO Department of Industry and Trade East Java Province [13]. There were three kinds of rice which would be forecasted. They were Bengawan, Mentik, and IR64. The forecasting is conducted using ARIMA method. Based on ARIMA method, the best ARIMA to forecast the price and support the review that rice policy is unsuitable are ARIMA $(4,1,2)$ for bengawan rice, $\operatorname{ARIMA}(3,1,2)$ for mentik rice, and ARIMA $(2,1,2)$ for IR64 rice. It is important to review again about policy of rice HET by considering supply and demand on rice maket. The indication of monopolistic behaviour on rice market could not be denied in line with the development of rice as consumer goods. If in this case BULOG (Logistic Affair Agency) takes a role on rice downstream, it is necessary to review again related to the determination of $H E T$ and supported facilities to improve rice brand of local farmer so that farmer share and bargaining position of farmer increases.
\end{abstract} price

Keywords-ARIMA; forecasting; government policy; rice

\section{INTRODUCTION}

East Java Province is one province that has a surplus of food, especially rice [1]. As a political commodity, rice is a necessity for all people to show increasing price symptoms [2]. The price of rice which is very diverse from the lowest for medium rice is $9,415 / \mathrm{kg}$ to $11,322 / \mathrm{kg}$ of premium rice (East Java Provincial Office of Industry and Trade, 2018) is one of the problems in stabilizing rice prices. Government intervention for rice price stabilization in the form of government purchase price (HPP) policy and highest retail price (HET) [3] seems not effective, both in terms of supply and demand (government failure).
Stabilization of staple food prices is a problem faced by various countries [4]. Factors affecting food price stability include increasing population, climate change, international trade barriers, and biofuel use trends [5]. Fluctuating staple food prices will cause losses for the entire agribusiness chain, starting from producers, processing, intermediary traders and consumers [6]. Ultimately this loss will cause social unrest so that each country intervenes in policies to maintain the stabilization of prices of staple foods which in Indonesia is the duty of the National Logistics Agency [7].

In fulfilling the task of stabilizing the price of basic commodities, the National Logistics Agency has the basis of regulations issued by the government, including Law Number 18 of 2012 [8] concerning Food and Law Number 7 of 2014 [9] concerning Trade. Both laws are related to the stabilization of food prices and food security. The mandate of the Act is that the central and regional governments have the task of controlling the availability of essential goods and / or important goods in the entire territory of the Republic of Indonesia. These goods must be available in sufficient quantities, of good quality, and at reasonable prices to maintain affordability at the consumer level while protecting producer income [10].

Food commodity prices have an important role in controlling inflation. The increase in food prices is classified by the Central Statistics Agency (BPS) as a component of volatile foods (volatile foods) because of its nature which is easily influenced by the harvest, natural disruptions, domestic and international food commodity prices. Its significant contribution to inflation and its rapid response to various shocks make it feasible to be used as inflation leading indicators [11]. [12] research results also show that the prices of food commodities tend to increase by 5-12 percent per year during the period 1999-2011. Some food commodities that are important in controlling inflation and tend to experience price increases are rice and from spices. This condition is different from the theory presented by Engel which states that an increase in income will increase people's welfare so that the share of household food consumption expenditure will decrease. The share of public expenditure on staple foods tends to be constant which shows that people still use their expenditure to meet food needs. 
As mandated in Law Number 7 of 2014 [13], the government is obliged to provide food for all people at affordable and stable prices. Price fluctuations and increases that tend to occur every year will greatly affect the purchasing power of people, especially low-income people. Society will be increasingly difficult to reach the level of food commodity prices. This will have an impact on people's difficulties in meeting other fields such as health and education [14].

The increase in prices of staple foods can have a domino effect on the Indonesian economy. The increase in prices of staple foods can cause inflation. In addition, price increases will gradually make a decrease in people's purchasing power which can harm producers. The increase in prices of staple foods generally occurs on certain days. In addition to the influence of demand and supply, certain days, such as religious holidays, tend to increase prices despite guaranteed and safe stocks. In its development, the government through Bulog intervened in stock security and price assurance so that no party was harmed. Government intervention needs to be done, one of which is to minimize fraud that can arise due to parties who use the time to take profits only.

The rice policy, especially the determination of prices has been sought by the Government in order to create prosperity at the producer and consumer level [15]. On the producer side, pursuant to Perpres Number 48 of 2016, the Bulog bought 10 percent of farmers' grain from the stipulated HPP so that the purchase price of dry milled grain (GKG) which was originally $4600 / \mathrm{kg}$ to $5,060 / \mathrm{kg}$. The price increase was met by the National Logistics Agency (Bulog) by taking food reserve funds reinforced by improving the quality of farmers' grain. Whereas to protect consumers, Bulog reduced HET from $9,450 / \mathrm{kg}$ to $8,950 / \mathrm{kg}$ for medium rice. Rice HET for medium quality is Rp9 $450,00 / \mathrm{kg}$ for the Java region while rice HET for premium quality is $\quad \mathrm{Rp} 12800,00 / \mathrm{kg}$ for the Java region. The HET is stipulated in the regulation of the Minister of Trade of the Republic of Indonesia Number 57/MDAG/PER/8/2017 concerning the determination of the highest retail price of rice with the determination of one of them based on the sales area. The HET is considered too low to absorb farmers' rice so that the rice processing industry is the choice of farmers to sell rice and their products are the choice of middle and upper economic class consumers, especially people in urban areas.

It is important to review the rice HET policy by considering the supply and demand in the rice market that whether the uniformity of rice prices with the application of HET is still needed in the rice market if you see the differentiation of rice products based on the attributes inherent in diverse rice brands and targeting different market segments different. The existence of indications of monopolistic behavior in the rice market cannot be denied in line with the development of rice as consumer goods. If in this case the National Logistics Agency (BULOG) takes a role in the downstreaming of rice, it is necessary to review the HET determination and support facilities to increase the rice brand of local farmers so that the farmer shares and the bargaining position of farmers increases. Reviewing the determination of rice HET which is considered too low compared to market prices and considering the monopolistic behavior that began to take shape in the rice market is expected to be the Government's entry point for positioning farmers' rice into branded packaged rice as quality food products that compete in the market.

This study aims to determine the effectiveness of government intervention through HET on the stability of rice prices while at the same time improving the welfare of farmers. The results of this study are expected to be taken into consideration in directing rice policies from upstream to downstream.

\section{RESEARCH METHODS}

This research was conducted with an econometric approach using time series data to see prices in the future. Data forecasting for the future is done as a tool to see that there is an increase in rice prices above the level set by the government, especially on certain days such as national religious holidays. The data used is secondary data from the East Java Provincial Office of Industry and Trade. The data was taken in the period January 2014 - July 2018. The price data for rice used included Bengawan rice, Mentik rice, and IR64 rice. Forecasting activities will be carried out for 12 months so that forecasting will be carried out from August 2018 - July 2019. Econometrics approach is done using ARIMA forecasting method (Autoregressive Integrated Moving Average) which will be processed using Eviews.

Forecasting is a study to estimate future events using existing data in the past [16]. Important forecasting steps are (1) Analyzing past data that is useful for patterns that occurred in the past. (2) Determine the data used because a good method is a method that provides predictive results that are not much different from the reality that occurs, and (3) Projects the past data using the method used, and considers the existence of several factors of change.

ARIMA (Autoregressive Integrated Moving Average) is one of the time series analysis techniques that is widely used for forecasting future models. The ARIMA model ignores the independent variables in modeling and uses past and present values of the dependent variable. ARIMA can be combined using artificial neural networks to get more comprehensive results and better validity [17]. ARIMA is often referred to as the Box Jenkins time series method. The Box-Jenkins method is an iterative choice of the best model for the stationary series of a group of linear time series models with the assumption that the series value is generated by a stochastic (random) process with an explanationable form. The Jenkins Box procedure consists of identification, estimation, evaluation of modeling, and forecasting. The ARIMA model combines the autoregressive (AR) model with p-order and the moving average (MA) model with q-order and differencing processes with order $\mathrm{d}$. 
Determination of $p$ and $q$ order values can be seen using correlogram on the autocorrelation function (ACF) and partial autocorrelation function (PACF) components and the determination of $\mathrm{d}$ order is determined by the number of differencing processes performed to obtain stationary data.

The first step taken in ARIMA modeling is to test stationary data used to avoid spurious regression models which result in insignificant and biased regression results. The stationary data test was performed with the unit root test (unit root test) using augmented dickey fuller test (ADF test). Data is called stationary if the data does not contain unit roots with the hypothesis:

$$
\begin{aligned}
& \mathrm{H} 0=\text { the data contains the unit root (not stationary) } \\
& \mathrm{H} 1=\text { data does not contain root unit (stationary) }
\end{aligned}
$$

Hypothesis testing by comparing ADF statistics with critical values which if the ADF statistics is greater than the critical value then the data is stationary and does not need to be differencing. If on the contrary, it is necessary to do a differencing process until the data is stationary. After the stationary data, then modeling ARIMA temporarily by determining the order $\mathrm{p}, \mathrm{q}$, and $\mathrm{d}$. The determination of the maximum order of AR (p) that needs to be observed is PACF, the maximum order determination of MA (q) that needs to be observed is ACF, and the determination of the maximum order of differencing (d) is the level of data stationarity. In choosing the best ARIMA model by looking at the smallest value of akaike information criteria (AIC) and schwartz criterion (SC).

The ARIMA equation model is formed [19]:

$$
X_{t}=\Phi_{1} X_{t-1}+\ldots+\Phi_{p} X_{t-p}+\varepsilon_{t}-\theta_{1 \varepsilon(t-1)}-\ldots-\theta_{q \varepsilon(t-q)}
$$

\section{RESULTS AND DISCUSSION}

Rice as one of the staple foodstuffs of Indonesian people who have strategic value and have influence in the economic, environmental and socio-political fields so that the availability of safe rice is important in achieving stable food security [2]. East Java is one of the rice barns and acts as a national food buffer [18]. The stability of rice prices is something that must be considered especially for policy makers. This stability will affect the occurrence of inflation in Indonesia. Rice is a commodity that has high volatility [5] especially when national religious holidays occur. Bulog is an agency that is given the responsibility to take steps to stabilize prices of staple foods, especially rice. There are three types of rice handled by Bulog, namely Bengawan, Mentik and IR64.

Based on the graph in figure 1 it can be seen that the trend of rice prices in East Java shows an increasing trend. Bengawan rice is in the same price range as mentik rice with Bengawan rice is slightly more expensive than mentik. While IR64 type of rice is cheaper than the other two types of rice.

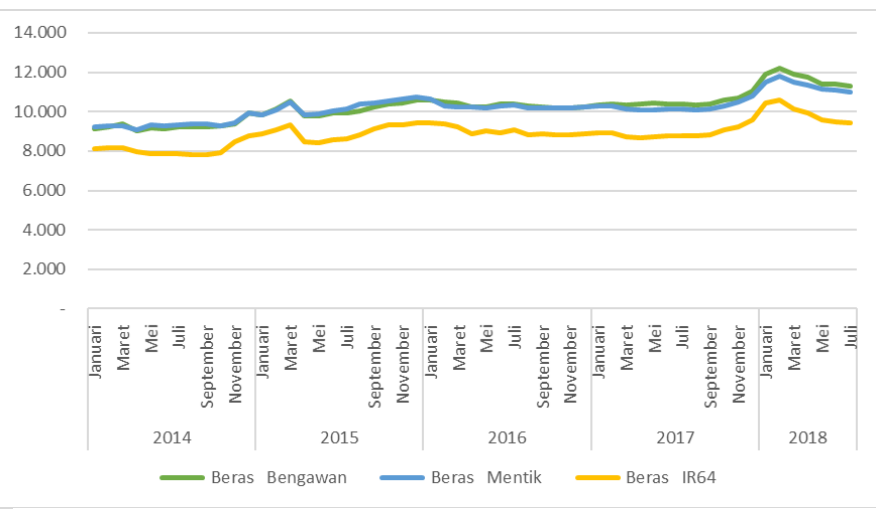

Fig. 1. Development of Rice Prices in East Java

\section{A. Bengawan Rice}

The price of bengawan rice that will be predicted is the price in August 2018 - July 2019. Before forecasting the price of rice, the price data is first carried out by stationary test. The trend of increasing the price of Bengawan rice shows a change in the average which means that there is an indication that the data is not stationary. Based on the ADF Test shows that in the data level, p-value (probability $\neg$ ) is greater than the real level ( $\alpha=5$ percent) that is at the value of $0.6619(0.6619>0.05)$. This shows that the data is not stationary and needs to be differencing. On 1st differencing shows that $\mathrm{p}$-value is smaller than the real level $(0.00<0.05)$ so it can be concluded that the data is stationary on the 1 st differencing.

TABLE I. ADF Test Results on Bengawan Rice Price Data

\begin{tabular}{|c|c|c|}
\hline \multirow{2}{*}{ Variabel } & \multicolumn{2}{|c|}{ Intercept } \\
\cline { 2 - 3 } & $\boldsymbol{t}$-Statistic & Probability \\
\hline $\mathrm{I}(0)$ & -1.2145 & 0.6619 \\
\hline $\mathrm{I}(1)$ & -6.2480 & 0.0000 \\
\hline
\end{tabular}

After the stationary data, then the temporary modeling of ARIMA is carried out. Forming a temporary ARIMA model by specifying the order AR (p) and MA (q). In determining the order can be seen from ACF and PACF. If PACF at a time lag period violates the boundary line then the time lag period becomes the maximum order candidate for AR. To determine the maximum order of MA, ACF is observed by looking at a

\begin{tabular}{|c|c|c|c|c|c|c|}
\hline $\begin{array}{c}\text { Auto } \\
\text { correlation }\end{array}$ & $\begin{array}{c}\text { Partial } \\
\text { Correlation }\end{array}$ & & AC & PAC & Q-Stat & Prob \\
\hline$\left.\right|^{*}$ &.$|*|$. & 1 & 0.132 & 0.132 & 0.9873 & 0.320 \\
\hline.$* 1$. & .*1. & 2 & -0.074 & -0.093 & 1.3097 & 0.520 \\
\hline . ${ }^{*}$. & $.1^{*}$ & 3 & 0.075 & 0.101 & 1.6461 & 0.649 \\
\hline$* * \mid$. & $* *||$. & 4 & -0.271 & -0.315 & 6.0830 & 0.193 \\
\hline$* * \mid$ &.$* 1$. & 5 & -0.218 & -0.121 & 9.0259 & 0.108 \\
\hline.$* 1$. &.$*|. \quad|$ & 6 & -0.095 & -0.132 & 9.6000 & 0.143 \\
\hline .1 .1 & .1 .1 & 7 & -0.002 & 0.057 & 9.6004 & 0.212 \\
\hline$. * 1 . \quad \mid$ & $* * \mid$ & 8 & -0.086 & -0.192 & 10.087 & 0.259 \\
\hline . |*. | & $.1^{*}$. & 9 & 0.096 & 0.084 & 10.703 & 0.297 \\
\hline.$||$. & .*1. | & 10 & 0.030 & -0.159 & 10.763 & 0.376 \\
\hline
\end{tabular}
time lag period that violates the limit.

TABLE II. CORRELOGRAM RESUlt to DETERMine AR AND MA ORDO 
Based on correlogram can be seen the maximum order that can be a temporary ARIMA model. The best ARIMA model is chosen by fulfilling the selection criteria which has the smallest akaike information criteria (AIC) and schwartz criterion (SC) values.

TABLE III. RESUlts OF ARIMA Model

\begin{tabular}{|c|c|c|c|}
\hline ARIMA & AIC & SC & R-Squared \\
\hline ARIMA $(1,1,1)$ & -4.8802 & -4.7329 & 11.37 \\
\hline ARIMA $(1,1,4)$ & -4.9396 & -4.6818 & 28.87 \\
\hline ARIMA $(2,1,2)$ & -4.8904 & -4.6695 & 21.56 \\
\hline ARIMA $(2,1,4)$ & -4.9138 & -4.6192 & 30.29 \\
\hline ARIMA $(3,1,4)$ & -4.8826 & -4.5511 & 30.73 \\
\hline ARIMA $(4,1,2)$ & -4.8970 & -4.7833 & 29.00 \\
\hline
\end{tabular}

The temporary ARIMA model can be seen in table 3 and based on the AIC and SC criteria it is determined that the best ARIMA model is ARIMA (4, 1, 2). Forecasting can be done after the best ARIMA model is determined.

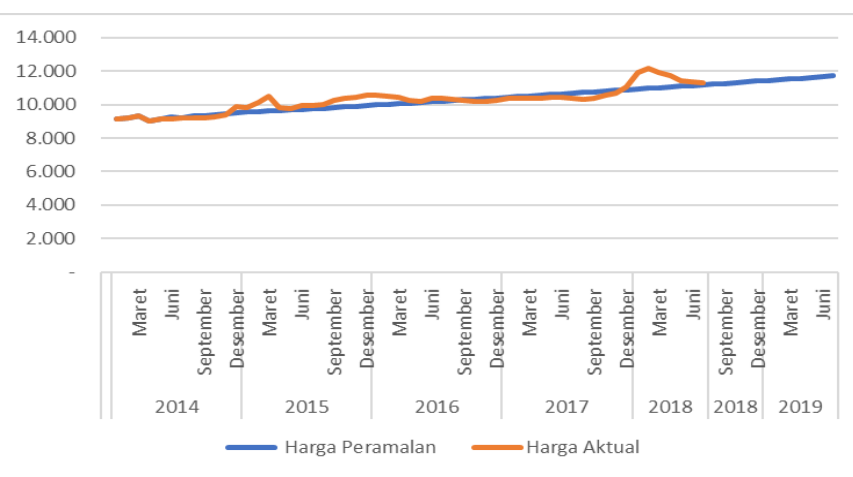

Fig. 2. Comparison of Actual Prices and Forecasting Prices

\section{B. Mentik Rice}

Mentik rice price that will be predicted is the price in August 2018 - July 2019. Based on the ADF Test shows that in the data level, p-value (probability $\neg$ ) is greater than the real level ( $\alpha=5$ percent) which is at the value of $0.5618(0.5618>$ $0.05)$. This shows that the data is not stationary and needs to be differencing. On 1st differencing shows that p-value is smaller than the real level $(0.00<0.05)$ so it can be concluded that the data is stationary on the 1 st differencing.

TABLE IV. ADF Test Results On MeNtik Rice Price Data

\begin{tabular}{|c|c|c|}
\hline \multirow{2}{*}{ Variabel } & \multicolumn{2}{|c|}{ Intercept } \\
\cline { 2 - 3 } & $\boldsymbol{t}$-Statistic & Probability \\
\hline $\mathrm{I}(0)$ & -2.9166 & 0.5618 \\
\hline $\mathrm{I}(1)$ & -6.3347 & 0.0000 \\
\hline
\end{tabular}

After the stationary data, then the temporary modeling of ARIMA is carried out. Forming a temporary ARIMA model by specifying the order AR (p) and MA (q).
TABLE V. CoRrelogram Results to Determine the ORder OF AR AND MA

\begin{tabular}{|c|c|c|c|c|c|c|}
\hline $\begin{array}{c}\text { Auto } \\
\text { correlation }\end{array}$ & $\begin{array}{c}\text { Partial } \\
\text { Correlation }\end{array}$ & & AC & PAC & Q-Stat & Prob \\
\hline$.\left.\right|^{*} \mid$ & $.\left.\right|^{*} . \quad \mid$ & 1 & 0.113 & 0.113 & 0.7293 & 0.393 \\
\hline.$||$. &.$||$. & 2 & -0.036 & -0.050 & 0.8058 & 0.668 \\
\hline$.\left.\right|^{*} . \mid$ & $.\left.\right|^{*} . \quad \mid$ & 3 & 0.110 & 0.121 & 1.5170 & 0.678 \\
\hline$* *||$. & $* *||$. & 4 & -0.278 & -0.317 & 6.1820 & 0.186 \\
\hline.$*||$. &.$*||$. & 5 & -0.154 & -0.067 & 7.6512 & 0.177 \\
\hline.$||$. &.$*||$. & 6 & -0.054 & -0.084 & 7.8366 & 0.250 \\
\hline.$||$. & $.\left.\right|^{*} . \mid$ & 7 & 0.028 & 0.126 & 7.8874 & 0.343 \\
\hline.$*||$. &.$*||$. & 8 & -0.084 & -0.197 & 8.3549 & 0.400 \\
\hline.$||$. &.$||$. & 9 & -0.002 & 0.007 & 8.3551 & 0.499 \\
\hline$.\left.\right|^{*} . \mid$ &.$||$. & 10 & 0.103 & 0.009 & 9.0807 & 0.524 \\
\hline
\end{tabular}

Based on correlogram can be seen the maximum order which can be a temporary ARIMA model.

TABLE VI. Results Of ARIMA Model

\begin{tabular}{|l|c|c|c|}
\hline \multicolumn{1}{|c|}{ ARIMA } & AIC & SC & R-Squared \\
\hline ARIMA $(1,1,1)$ & -4.9779 & -4.8306 & 7.56 \\
\hline ARIMA $(1,1,4)$ & -5.0137 & -4.7558 & 23.88 \\
\hline ARIMA $(2,1,2)$ & -4.9637 & -4.7427 & 15.75 \\
\hline ARIMA $(2,1,4)$ & -4.9766 & -4.6820 & 23.89 \\
\hline ARIMA $(3,1,2)$ & -5.0355 & -4.7776 & 28.34 \\
\hline ARIMA $(4,1,2)$ & -4.9733 & -4.6786 & 23.90 \\
\hline
\end{tabular}

The temporary ARIMA model can be seen in table 3 and based on the AIC and SC criteria it is determined that the best ARIMA model is ARIMA $(3,1,2)$. Forecasting can be done after the best ARIMA model is determined.

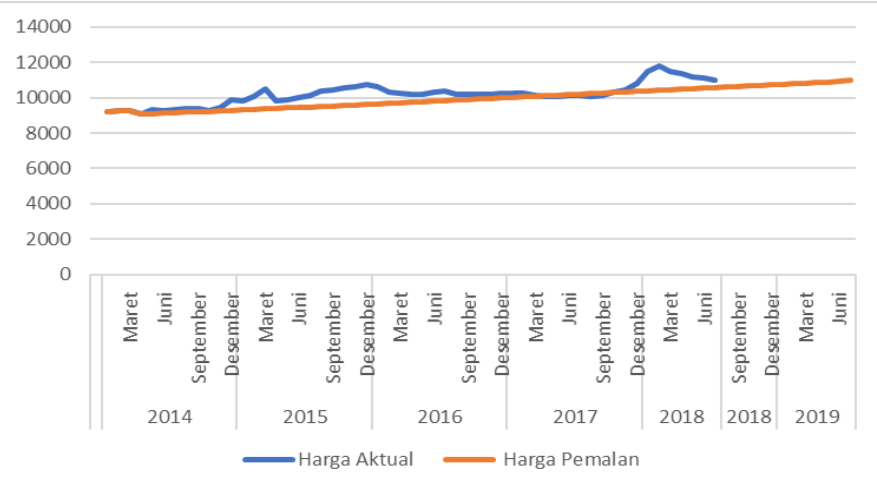

Fig. 3. Comparison of Actual Prices and Forecasting Prices

\section{IR64 Rice}

The IR64 rice price that will be predicted is the price in August 2018 - July 2019. Based on the ADF Test shows that in the data level, p-value (probability $\neg$ ) is greater than the real level ( $\alpha=5$ percent) which is at the value $0.2617(0.2617>$ $0.05)$. On 1 st differencing shows that $\mathrm{p}$-value is smaller than the real level $(0.00<0.05)$ so it can be concluded that the data is stationary on the 1 st differencing. 
TABLE VII. ADF Test Results On IR64 Rice PRICE DATA

\begin{tabular}{|c|c|c|}
\hline \multirow{2}{*}{ Variabel } & \multicolumn{2}{|c|}{ Intercept } \\
\cline { 2 - 3 } & $\boldsymbol{t}$-Statistic & Probability \\
\hline $\mathrm{I}(0)$ & -2.0590 & 0.2617 \\
\hline $\mathrm{I}(1)$ & -5.2932 & 0.0000 \\
\hline
\end{tabular}

After the stationary data, then the temporary modeling of ARIMA is carried out. Forming a temporary ARIMA model by specifying the order AR (p) and MA (q).

TABLE VIII. CORRELOGRAM RESULTS TO DETERMINE THE ORDER OF AR AND MA

\begin{tabular}{|c|c|c|c|c|c|c|}
\hline $\begin{array}{c}\text { Auto } \\
\text { correlation }\end{array}$ & $\begin{array}{c}\text { Partial } \\
\text { Correlation }\end{array}$ & & AC & PAC & Q-Stat & Prob \\
\hline.$|* *|$ & $. *^{* *} \mid$ & 1 & 0.288 & 0.288 & 4.7443 & 0.029 \\
\hline.$||$. &.$||$. & 2 & 0.025 & -0.063 & 4.7819 & 0.092 \\
\hline.$||$. &.$||$. & 3 & -0.041 & -0.033 & 4.8811 & 0.181 \\
\hline.$*||$. &.$*||$. & 4 & -0.151 & -0.140 & 6.2652 & 0.180 \\
\hline$* * *||$. & $* *|. \quad|$ & 5 & -0.364 & -0.315 & 14.460 & 0.013 \\
\hline$* *||$. &.$||$. & 6 & -0.205 & -0.036 & 17.106 & 0.009 \\
\hline.$||$. &.$||$. & 7 & -0.064 & -0.026 & 17.371 & 0.015 \\
\hline.$||$. &.$*||$. & 8 & -0.043 & -0.071 & 17.493 & 0.025 \\
\hline.$||$. &.$||$. & 9 & 0.008 & -0.048 & 17.498 & 0.041 \\
\hline.$||$. &.$*||$. & 10 & 0.002 & -0.153 & 17.498 & 0.064 \\
\hline
\end{tabular}

Based on correlogram can be seen the maximum order that can be a temporary ARIMA model.

TABLE IX. ARIMA MODEL

\begin{tabular}{|c|c|c|c|}
\hline ARIMA & AIC & SC & R-Squared \\
\hline ARIMA $(1,1,2)$ & -4.4143 & -4.2307 & 18.59 \\
\hline ARIMA $(2,1,1)$ & -4.4466 & -4.2624 & 21.79 \\
\hline ARIMA $(2,1,2)$ & -4.4472 & -4.2262 & 28.39 \\
\hline ARIMA $(3,1,1)$ & -4.4164 & -4.1954 & 22.56 \\
\hline ARIMA $(4,1,3)$ & -4.3326 & -4.0012 & 27.69 \\
\hline ARIMA $(4,1,4)$ & -4.3956 & -4.0272 & 38.58 \\
\hline
\end{tabular}

The temporary ARIMA model can be seen in table 3 and based on the AIC and SC criteria it is determined that the best ARIMA model is ARIMA $(2,1,2)$. Forecasting can be done after the best ARIMA model is determined.

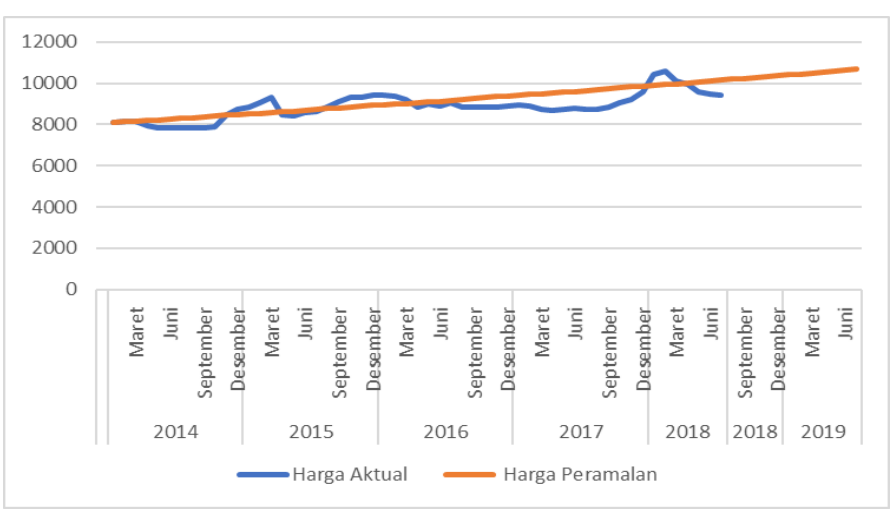

Fig 4. Comparison of Actual Prices and Forecasting Prices

\section{CONCLUSION}

The trend of the development of rice prices shows an increase especially ahead of national religious holidays. The ARIMA model produced for forecasting is ARIMA $(4,1,2)$ for bengawan rice, ARIMA $(3,1,2)$ for mentik rice, and ARIMA $(2,1,2)$ for IR64 rice. The price formed shows that the price of rice, especially the Mentik type and IR64 has exceeded the price set by the government. The policy that government has been made about rice price should be reviewed because the increasing of rice price cannot be denied. The market operation implementation can not always bet he main foundation for the government as a form of controlling prices.

\section{POLICY IMPLICATIONS}

It is important to review the rice HET policy by considering supply and demand in the rice market. The existence of indications of monopolistic behavior in the rice market cannot be denied in line with the development of rice as consumer goods. If in this case the National Logistics Agency (BULOG) takes a role in the downstreaming of rice, it is necessary to review the HET determination and support facilities to increase the rice brand of local farmers so that the farmer shares and the bargaining position of farmers increases. Furthermore, consumer get suitable rice based on their consumption preferences both on medium rice and premium without having to rely on the existance of fraud in the processor level and the business can innovate and improve rice quality which they bought from farmer without violating the government policy on price regulation.

\section{ACKNOWLEDGMENTS}

The authors gratefully thank to East Java Provincial Office of Industry and Trade to supporting our data research.

\section{REFERENCE}

[1] S. Pandey, T. Sulser, M.W. Rosegrant, and H. Bhandari, "Rice Price Crisis: Causes, Impacts, and Solutions," Asian J. Agric. and Dev., vol. 7, no. 2 , pp. $1-15,2010$.

[2] Nurliza. "The Nature of Food Commodity Prices Volatility in Driving Inflation and Policy," Signifikan: J. Ilmu Ekon., vol. 6, no. 1, pp. 103124, 2017.

[3] C.L. Gilbert and C.W. Morgan, "Food Price Volatility," Philos. Trans. R. Soc., vol. 365, pp. 3023-3034, 2010.

[4] M. Hossain, "What Implications Does The World Food Price Rise Have For Food Security in bangladesh," Int. J. Food Agric. Econ., vol. 2, no. 1 , pp. $51-63,2014$.

[5] F. Jezghani, R. Moghaddasi, S. Yazdzani, and A. Mohammadinejal, "Spatial Price Transmission: A Study of Rice Markets in Iran," World Appl. Sci. J., vol. 21, no. 4, pp. 646-650, 2013.

[6] F.U. Rehman and D. Khan, "The Determinants of Food Price Inflation in Pakistan: An Econometric Analysis," Adv. Econ. Bus., vol. 3, no. 12, pp. $571-576,2015$.

[7] H. Ahsan, Z. Iftikhar, and M.A. Kemal, "The Determinants of Food Prices in Pakistan," The Lahore J. Econ., vol. 17, no. 1, pp. 101-128, 2012.

[8] T. Andreyeva, M.W. Long, and K.D. Brownell, "The Impact of Food Prices on Consumption: A Systematic Review of Research on The Price Elasticity of Demand for Food," Am. J. Pub. Health, vol. 100, no. 2, pp. $216-222,2010$. 
[9] A. Doward, "The Short and Medium Term Impacts of Rises in Staple Food Prices," Food Secur., vol. 4, no. 4, pp. 633-645, 2012.

[10] S. Aftab, M.R. Yaseen, and S. Anwar, "Impact of Rising Food Prices on Consumer Welfare in The Most Populous Countries of South Asia," Int. J. Soc. Econ., vol. 44, no. 8, pp. 1062-1077, 2017.

[11] R. Clarke and D. Collie, "Product Differentiation and The Gains From Trade Under Bertrand Duopoly," Canadian J. Econ., vol. 36, no. 3, pp. 658-673, 2004.

[12] A. Dhini, I. Surjandari, M. Riefqi, and M.A. Puspasari, "Forecasting Analysis of Consumer Goods Demand Using Neural Networks and ARIMA,” Int. J. Technol., vol. 5, pp. 872-880, 2015.

[13] Y. E. Shao and J. Dai, "Integrated Feature Selection of ARIMA With Computational Intelligence Approaches for Food Crop Price Prediction," Complexity, vol. 2, pp. 1 - 17, 2018.

[14] Sarpong, "Smart. Modeling and Forecasting Maternal Mortality: An
Application of ARIMA Models," Int. J. Appl. Sci. Technol., vol. 3, no. 1 , pp. $19-28,2013$

[15] E. Jarrett and E. Kyper, "ARIMA Modeling With Intervention to Forecast and Analyze Chinese Stock Prices," Int. J. Eng. Bus. Manag., vol. 3, no. 3, pp. 53-58, 2011.

[16] N. Steve, "Autoregressive Integrated Moving Average (ARIMA) Model For Exchange Rate (Naira to Dollar)," Acad. J. Interdiscip. Stud., vol. 3, no. 4, pp. 429-433, 2014.

[17] K. Basu and C. Marks, "Understanding Inflation and Controlling It," Econ. Politic. Weekly, vol. 46, no. 41, pp. 50-64, 2011.

[18] A. Daniel and M. Nuhu, "Monetary Policy and Inflation Control in Nigeria," J. Econ. Sustain. Dev., vol. 6, no. 8, pp. 108-115, 2015.

[19] Himani, "Role of Monetary Policy in Combating Inflation," IOSR J. of Econ. and Financ. (IOSR - JEF), vol. 4, no. 6, pp. 11-20, 2014. 